Original Article

\title{
Extraction of chitin from edible crab shells of Callinectes sapidus and comparison with market purchased chitin
}

\author{
Extração de quitina de cascas de caranguejo comestíveis de Callinectes sapidus e \\ comparação com quitina adquirida no mercado
}

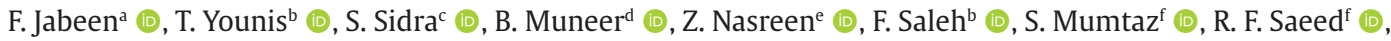 \\ A. S. Abbas ${ }^{g *}$ (D) \\ anniversity of Education, Department of Zoology, Lahore, Pakistan

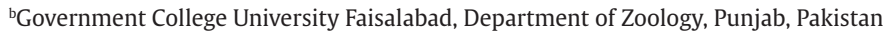 \\ cUniversity of Veterinary and Animal Sciences, Department of Wildlife and Ecology, Lahore, Pakistan \\ ${ }^{\mathrm{d} G o v e r n m e n t ~ C o l l e g e ~ U n i v e r s i t y, ~ I n s t i t u t e ~ o f ~ I n d u s t r i a l ~ B i o t e c h n o l o g y, ~ L a h o r e, ~ P a k i s t a n ~}$ \\ eUniversity of Mianwali, Mianwali, Pakistan \\ ${ }_{\mathrm{f}}$ National University Of Medical Sciences Rawalpindi, Department of biological sciences, Punjab, Pakistan \\ gUniversity of Education, Department of Zoology, Lahore, Pakistan
}

\begin{abstract}
Chitin and its derived products have immense economic value due to their vital role in various biological activities as well as biomedical and industrial application. Insects, microorganism and crustaceans are the main supply of chitin but the crustaceans shell like shrimp, krill, lobsters and crabs are the main commercial sources. Chitin content of an individual varies depending on the structures possessing the polymer and the species. In this study edible crabs' shells (Callinectes sapidus) were demineralized and deproteinized resulting in $13.8 \%$ (dry weight) chitin recovery from chitin wastes. FTIR and XRD analyses of the experimental crude as well as purified chitins revealed that both were much comparable to the commercially purchased controls. The acid pretreatment ceded $54 \mathrm{~g}$ of colloidal chitin that resulted in $1080 \%$ of the crude chitin. The colloidal chitin was exploited for isolation of eighty five chitinolytic bacterial isolates from different sources. Zone of clearance was displayed by the thirty five isolates $(41.17 \%)$ succeeding their growth at $\mathrm{pH} 7$ on colloidal chitin agar medium. Maximum chitinolytic activity i.e. $301.55 \mathrm{U} / \mathrm{ml}$ was exhibited by isolate JF70 when cultivated in extracted chitin containing both carbon and nitrogen. The study showed wastes of blue crabs can be utilized for extraction of chitin and isolation of chitinolytic bacteria that can be used to degrade chitin waste, resolve environmental pollution as well as industrial purpose.
\end{abstract}

Keywords: crab shells, chitin, chitinases, chitinolytic bacteria.

\begin{abstract}
Resumo
A quitina e seus produtos derivados têm imenso valor econômico devido ao seu papel vital em várias atividades biológicas, bem como em aplicações biomédicas e industriais. Insetos, microrganismos e crustáceos são o principal suprimento de quitina, mas a casca dos crustáceos como camarão, krill, lagosta e caranguejo são as principais fontes comerciais. O conteúdo de quitina de um indivíduo varia dependendo das estruturas que possuem o polímero e da espécie. Neste estudo, as cascas de caranguejos comestíveis (Callinectes sapidus) foram desmineralizadas e desproteinizadas, resultando em $13,8 \%$ (peso seco) de recuperação de quitina a partir de resíduos de quitina. As análises de FTIR e XRD do bruto experimental, bem como das quitinas purificadas, revelaram que ambas eram muito comparáveis aos controles adquiridos comercialmente. 0 pré-tratamento com ácido cedeu $54 \mathrm{~g}$ de quitina coloidal que resultou em $1.080 \%$ da quitina bruta. A quitina coloidal foi analisada para isolamento de 85 isolados bacterianos quitinolíticos de diferentes fontes. A zona de eliminação foi exibida pelos 35 isolados (41,17\%) que sucederam seu crescimento a pH 7 em meio de ágar de quitina coloidal. A atividade quitinolítica máxima, ou seja, 301,55 U / ml, foi exibida pelo isolado JF70 quando cultivado em quitina extraída contendo carbono e nitrogênio. O estudo mostrou que resíduos de caranguejos azuis podem ser utilizados para extração de quitina e isolamento de bactérias quitinolíticas que podem ser usadas para degradar resíduos de quitina, resolver a poluição ambiental e também para fins industriais.
\end{abstract}

Palavras-chave: caranguejo, quitina, quitinases, bactéria quitinolítica.

*e-mail: afshan.syed@ue.edu.pk

Received: December 12, 2020 - Accepted: February 18, 2021 


\section{Introduction}

Chitin is the most copious renewable natural polymer that assembled in marine invertebrates, insect's exoskeleton, cell walls of fungi and algae. Aquatic products which constitute of organisms loaded in chitinous matter are approximately $10 \%$ of total global landing and about $10^{12}$ tons of chitin wastes accumulates in ocean every year (Jahangiri et al., 2019; Ray et al., 2019; Sun et al., 2019). Ecdysis (shedding of cuticle) as well as senescence is the dynamic processes that consequent in unremitting hail of chitin to the ocean base which is recognized as marine snow, while there is no quantitatively significant accretion of chitin in sediments of ocean due to its efficient degradation and metabolization by bacteria (Elsoud and El Kady, 2019; Rameshthangam et al., 2018).

Among sea food the main commercial sources of chitin are crustacean shells due to their high content and ready availability (Ray et al., 2019; Xu et al., 2020). Crabs are being used in large quantity, producing considerable amount of their shell waste into the environment which can be utilized for chitin recovery and production of chitinases for degradation of heaps of chitin wastes. Chitinases can be constructed towards various valuable applications including biological control of pathogenic fungi (Liu et al., 2019; Loc et al., 2019) and harmful insects (Ray et al., 2019), production of single cell protein, production of biofuel, eradication of malaria and various application in food, agriculture, pharmaceuticals and chemical industries (Ali et al., 2020; Asif et al., 2019; Oyeleye and Normi, 2018).

Chitin is a linear polymer of $\mathrm{N}$-acetylglucosamine with $\beta$ (1-4) linkage and is insoluble in water. Chitin and its derived products has attracted a great attention and marketing power due to their possible applications in biotechnology including medicine, cosmetics, pharmacology, agriculture, biological control and wastewater treatment. Nonantigenicity, bio-compatibility, bio-degradability and non-toxicity are the useful biological activities which have been exhibited by chitin and its derived products. Recently they have displayed a high value-added application that is why gaining the interest of many investigators and made them curious for the new promising sources of chitin (Asif et al., 2019; Kumar and Zhang, 2019).

Several techniques have been proposed and used up till now for the chitin extraction from its diverse sources. Many of them depend upon the chemical procedures which involve the removal of protein and elimination of inorganic matter (demineralization). Some of them embrace the removal of pigment from extracted chitin which improves its color, by using chemical oxidation and solvent extraction method (Beaney et al., 2005; Yadav et al., 2019). For the chitin fabrication on commercial scale from crustaceans the conventional methods available are the removal of protein (deproteination) with alkali at high temperatures and mechanical grinding (demineralization) with strong acids (Pighinelli et al., 2019; Thirunavukkarasu and Shanmugam, 2009).

In this study we aimed to extract the chitin from edible blue crab and compared with market available purified chitin to exploit it to isolate chitinolytic bacteria. The exploitation of crab shell waste by potent bacteria would be projected not only to solve the issue of waste generation but also environmental problems.

\section{Materials and Methods}

\subsection{Ethical statement}

The study was conducted in accordance with declaration of University of the Punjab and the protocol was approved by Ethics committee of the said University.

\subsection{Crab collection}

Blue crab (Callinectes sapidus) was purchased from local sea food shop, washed with simple tap water and then meat was separated from the shell. The shells were dehydrated in oven at $105^{\circ} \mathrm{C}$ till its weight became constant then grinded to powder.

\subsection{Demineralization and deproteinization of crab shell}

Crab shells were treated according to the process given in (Jabeen and Qazi, 2014). For demineralization $5 \mathrm{~g}$ of shell powder was added in $0.55 \mathrm{M} \mathrm{HCl}(45 \mathrm{ml})$ for $2 \mathrm{~h}$ at room temperature. After that for deproteinization $0.3 \mathrm{M}$ sodium hydroxide $(100 \mathrm{ml})$ was added repeatedly for $1 \mathrm{~h}$ at $80^{\circ} \mathrm{C}$. Now the treated suspension was filtered and washed with distilled water two to three times. The powder on filter paper mainly containing chitin was dried and saved in dried bottle.

\subsection{Characterization of chitin}

\subsubsection{Fourier Transmission Infra Red spectroscopy (FTIR)}

Treated crab shells and market purchased chitin were analyzed on FTIR system. KBr pellets were used to prepare samples with 2:100 (w/w) i.e 2\%. Absorbance was taken with the resolution of $2 \mathrm{~cm}^{-1}$ and scan 4 .

\subsubsection{X.Ray Diffraction (XRD)}

Treated crab shells and market purchased chitin were analyzed on X-ray diffractograms and observed with $\mathrm{Cu}-\mathrm{K} \alpha$ (40 kV and $40 \mathrm{~mA}$ ) radiation with graphite chromators at $298 \mathrm{~K}$. The relative intensity was recorded in a 10 $85^{\circ}$ dispersion range $(2 \theta)$.

\subsubsection{Processing for colloidal chitin}

Colloidal chitin was achieved by technique given in (Jabeen and Qazi, 2014). Concentrated Hydrochloric acid $(60 \mathrm{ml})$ was added in $5 \mathrm{~g}$ chitin powder with vigorous shaking for $1 \mathrm{~h}$ and filtered through glass wool. The filtrate was treated with $200 \mathrm{ml}$ of $50 \%$ ethanol with continuous shaking. The colloidal chitin was filtered through filter paper and washed repeatedly with distilled water until the spent water became neutral. Colloidal chitin was separated from the filter paper, weighed and stored in brown bottle at $4^{\circ} \mathrm{C}$. 


\subsubsection{Isolation of chitinolytic bacteria}

Eighty five bacterial isolates were separated from different samples of soils containing insects, their mound and nearby areas of their dwellings. Samples were run on $1 \%$ colloidal chitin containing selective medium. Colony forming units (C.F.U.) in the samples were also counted on selective medium. Zone producing isolates were pure cultured and preserved on glycerol stocks.

\subsubsection{Estimation of chitinolytic activity}

Chitinolytic activity was assessed by reducing sugars released from the chitin following method of Sadafi et al. (Sadfi et al., 2001). The standard curve was plotted with $\mathrm{N}$-acetylglucosamine (NAG). One unit of chitinolytic activity was described as 1 micromole of GlcNAc per mg of protein per minute.

\section{Results and Discussion}

\subsection{Processing of chitin containing waste}

Commercially crab and shrimp shells are being used as chitin source for their availability and easy access. (Gadgey and Bahekar, 2017; Yadav et al., 2019). Jabeen and Qazi (Jabeen and Qazi, 2014) reported that chitin is most renewable resource as tons of chitin is produced every year on earth. The utilization of insect waste while solving an environmental problem will decrease the production costs of microbial chitinases. Because of hydrophobic property, its degradation is not easily possible due to its inert behavior but it has the potential for bioconversion to monomers (GluNAc) and chito-oligosaccharides by enzyme-catalyzed reactions (Jung and Park, 2014; Schmitz et al., 2019).
Chitin was used as only carbon source for chitinases production which has abundantly produced by food industries. Different chemical and biological pretreatments methods to enhance production have been reported. In the present study blue crabs shells were cleaned, mashed and ground, then demineralization and deproteinization was carried out for removal of minerals and proteins respectively. After processing and dehydraion $0.55 \mathrm{~g}$ chitin was obtained that recovered $13.8 \%$ of the total crab shell waste. These results are in accordance with the work of many workers. Pandharipande and Bhagat (2016) reported the yield of chitin between $10.60-12.73 \%$, extracted from crab shells. Narudin et al. (2020) also declared that from crab $11.73 \%$ chitin content was achievable. Crabs and its shells used are shown in Figure 1.

Colloidal chitin was prepared with acid pretreatment for easy utilization of chitinolytic bacteria. Chitin after acid treatment yielded $54 \mathrm{~g}$ of colloidal chitin which was $1080 \%$ of the crude chitin. Song et al. (2020) reported that colloidal chitin was utilized more rapidly than crude chitin. The specific method thus adapted in this study for preparing colloidal chitin capitulate slightly higher colloidal than other methods examined by various workers. This method is also relatively quicker than many others and the product is easy to be uptaken by bacteria. While estimating the chitin utilization rate, Seki(Seki, 1965 ) found that $10^{10}$ bacterial cells in $1 \mathrm{~cm}^{3}$ of the soil, could decompose about $30 \mathrm{mg}$ each day at $25^{\circ} \mathrm{C}$. He also estimated that chitin in ocean gets decomposed within 140 days at $15^{\circ} \mathrm{C}$ and required 370 days at $5^{\circ} \mathrm{C}$, whereas below $5^{\circ} \mathrm{C}$ it acquire 500 or more days.

\subsection{XRD and FTIR analysis of chitin}

XRD analysis of the commercial chitin revealed a difference of peak around 25 angle which was present only in case of Roth. The sigma chitin had an additional peak
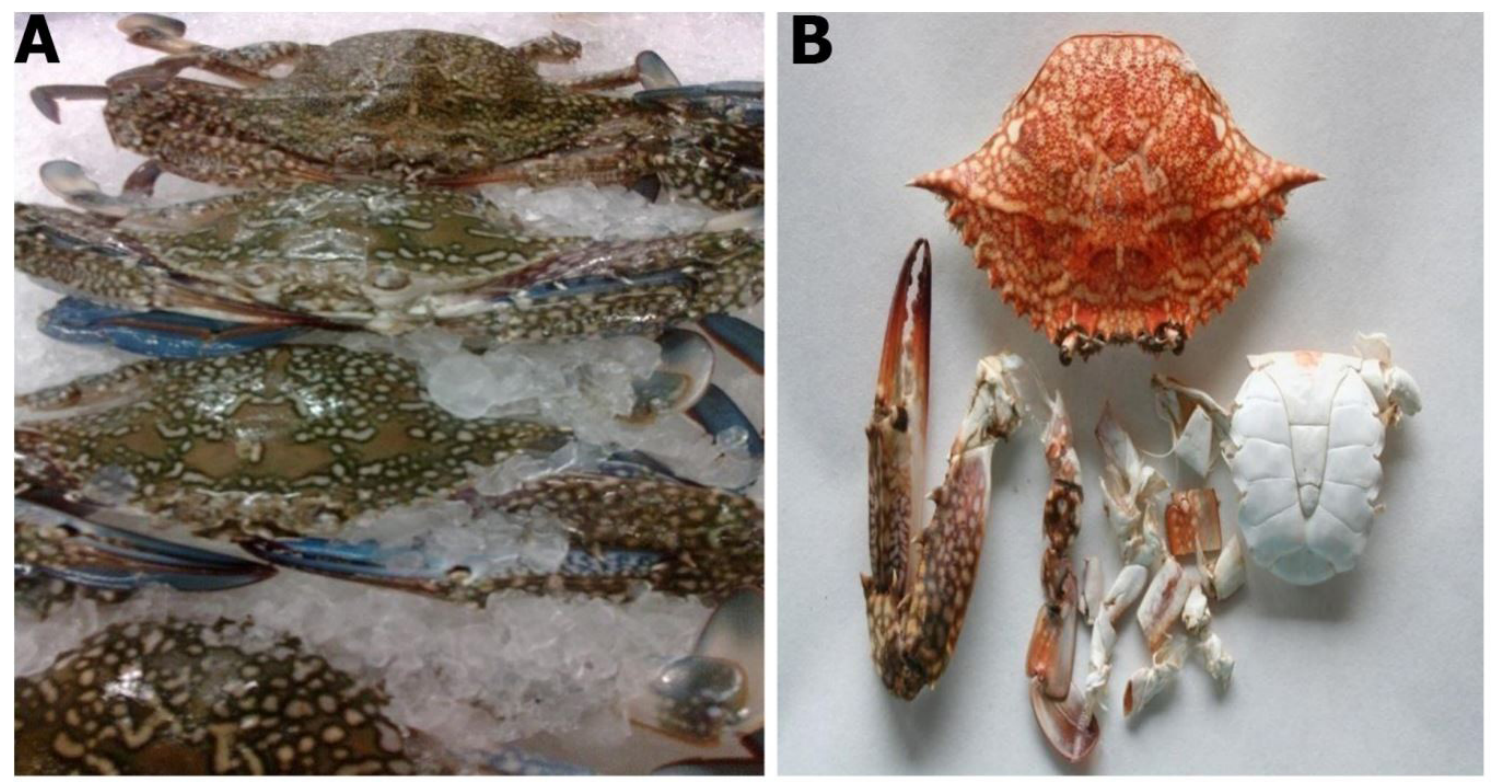

Figure 1. Edible blue crabs (Callinectus sapidus) (A) and parts used for the isolation of chitin polymer (B). 
around 50 angle representing the last plateau (Figure 2). The crude chitin had a very close general look with the Sigma, expecting having an additional peak around 29 angle and higher intensity of the peak at 43 angle. However, the purified chitin had a mimic pan of XRD analysis with that of Sigma chitin (Figure 2).

A sharp peak is appeared in sigma, Roth and purified blue crab chitin near $19^{\circ}$, not found in crude shell and weak peaks after $20^{\circ}$. In other studies, XRD peaks of $\alpha$-chitin observed from various organisms i.e. shrimp, crab, krill, anthozoa, and insects sharply peak around $12^{\circ}$, with weak peaks around 19, 23 and $26^{\circ}$ (Wang et al., 2013). These results showed that shell of $C$. sapidus is mainly consisted of $\alpha$-chitin.

FTIR analyses of the two commercially purified chitin i.e. Sigma and Roth revealed small differences in the percent transmittance upto wave number 1800, there after the detailed differences became prominent for a very short segment of wave number. An overview throughout wave spectra from 390 upto 1100, however, depicted a comparable trend (Figure 3 ). The crude as well as purified chitin prepared during course of this study had quite much comparable patterns of the percent transmittances with more prominent vertical oscillation in case of purified polymer (Figure 3 ). The chitins extracted and purified in this study resemble more closely in term of \% transmittance to that of Roth as compare to Sigma. FTIR patterns showed the bands all corresponds to stretching and vibration of $\mathrm{O}-\mathrm{H}, \mathrm{N}-\mathrm{H}$ and $\mathrm{CO}$ bonds as given in Table 1 .

\subsection{Isolation and screening of chitinolytic bacteria.}

Although chitinase producing organism are wide spread in nature, microbes have been exploited as preferred source because of their rapid enzymes production, limited requirement of cultivation space and their easy enzyme extraction protocols from fermented broth (Gupta et al., 2017). Chitinase production is found in many microorganisms; and among them large numbers of bacterial species is known to produce chitinases. Considering the richness of microbial diversity, there is always a chance of new variety carrying better enzymatic character and their suitability for commercial exploitation always exists.

Eighty five bacterial isolates were separated from samples comprising insects, their mounds and their affected fields. Samples were processed on selective agar medium
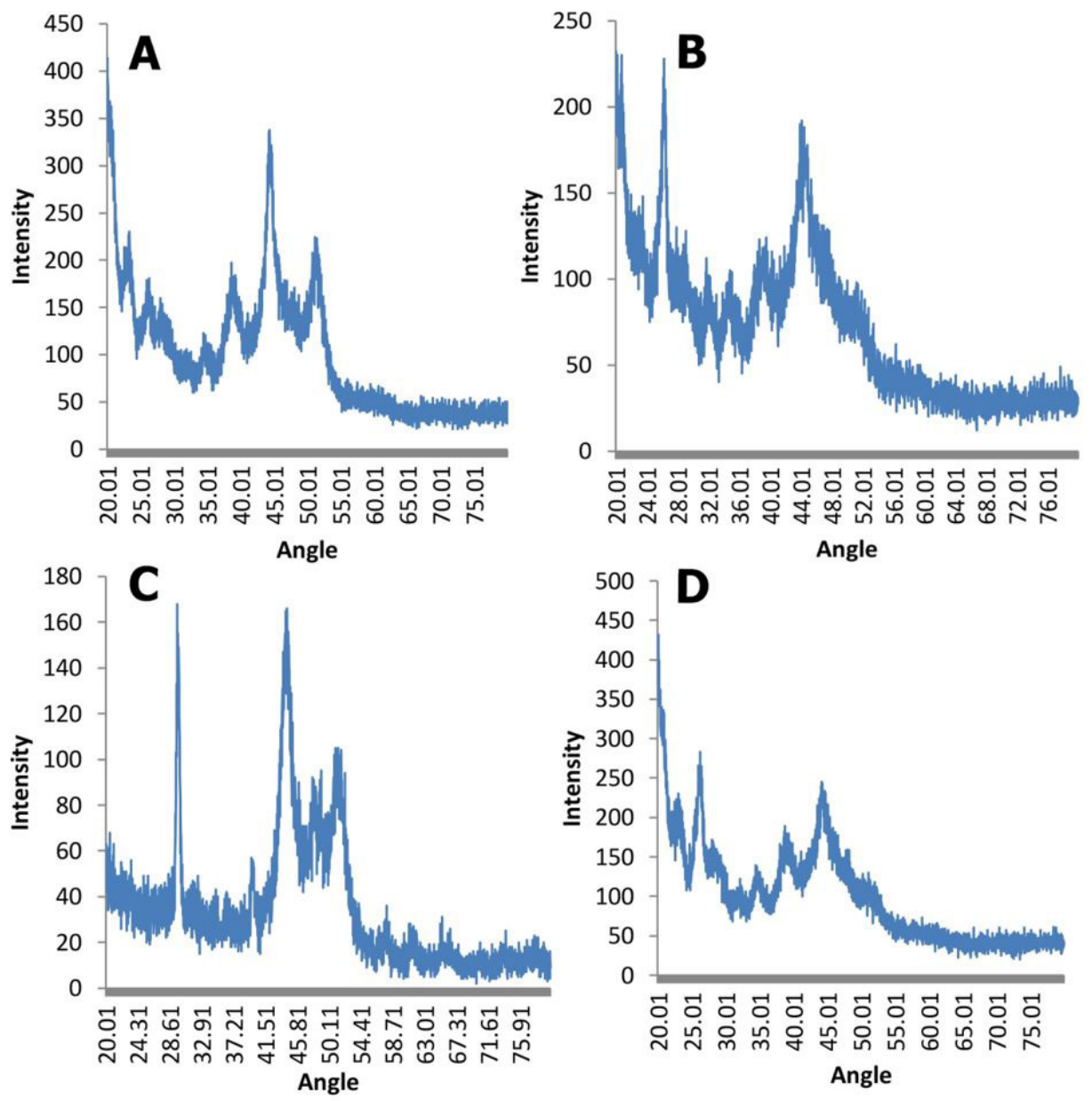

Figure 2. XRD spectra of Sigma (A); Roth (B); blue crab (Callinectes sapidus) crude (C); and purified chitins (D). 

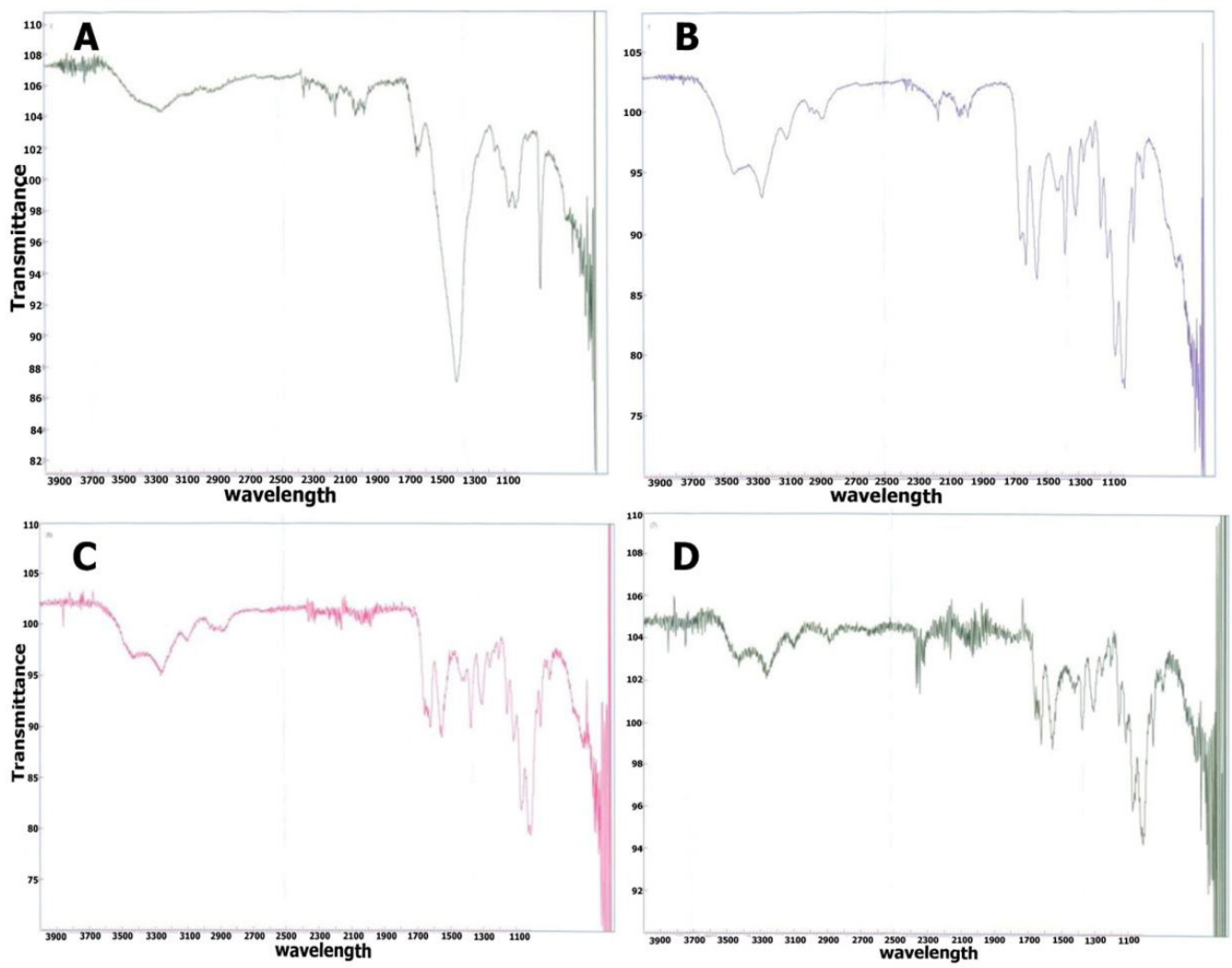

Figure 3. FTIR analysis of Sigma (A); Roth (B); Blue crab (Callinectes sapidus) crude (C); and Purified chitins (D).

Table 1. The FT-IR bands $\left(\mathrm{cm}^{-1}\right)$ of other commercial chitin (Kaya et al., 2015).

\begin{tabular}{|c|c|c|}
\hline Functional group and vibration modes & Classification & Other commercial chitin \\
\hline $\mathrm{O}-\mathrm{H}$ stretching & - & 3437 \\
\hline $\mathrm{N}-\mathrm{H}$ stretching & - & $3101-3259$ \\
\hline $\begin{array}{l}\mathrm{CH}_{3} \text { symmetrical stretch and } \mathrm{CH}_{2} \text { asym- } \\
\text { metric stretch }\end{array}$ & Aliphre2watic compounds & 2937 \\
\hline $\mathrm{CH}_{3}$ symmetrical stretch & Aliphatic compound & 2867 \\
\hline C-O secondary amide stretch & Amide I & 1654 \\
\hline C-O secondary amide stretch & Amide I & 1620 \\
\hline $\mathrm{N}-\mathrm{H}$ bend, $\mathrm{C}-\mathrm{N}$ stretch & Amide II & 1553 \\
\hline $\mathrm{CH}_{2}$ ending and $\mathrm{CH}_{3}$ deformation & - & 1430 \\
\hline $\mathrm{CH}$ bends $\mathrm{CH}_{3}$ symmetrical deformation & - & 1376 \\
\hline $\mathrm{CH}_{2}$ wagging & $\begin{array}{l}\text { Amide III, components } \\
\text { of protein }\end{array}$ & 1318 \\
\hline Asymmetric bridge oxygen stretching & - & 1155 \\
\hline $\begin{array}{l}\text { Asymmetric in-phase ring stretch- } \\
\text { ing mode }\end{array}$ & - & 1114 \\
\hline $\mathrm{C}-\mathrm{O}-\mathrm{C}$ asymmetric stretch in phase ring & Saccharide rings & 1068 \\
\hline $\mathrm{C}-\mathrm{O}$ asymmetric stretch in phase ring & - & 1024 \\
\hline $\mathrm{CH}_{3}$ wagging & Along chain & 952 \\
\hline $\mathrm{CH}$ ring stretching & Saccharide rings & 896 \\
\hline
\end{tabular}


containing chitin the only carbon source. Among isolates bacterial 35 exhibited vivid hydrolysis zone at $\mathrm{pH}$ 6.0. Maximum ZS to CS ratio was $5.0 \mathrm{~mm}$ (Table 2).

Based upon the chitin hydrolysis zones thirty bacterial isolates were selected for further study. The larger and clearer the zone of chitin hydrolysis, the more efficient the bacterial isolate was considered. The method was considered as primary quantitative test for confirmation of chitinolytic bacteria. The ratio of the zone size and colony size indicates the extent of chitinolytic exoenzymes diffusibility. It represents simple and inexpensive method for the isolation of chitinolytic bacteria from pool of bacterial diversity.

Table 2. chitin hydrolysis, growth and chitinase activity on chitin medium following 5 days of growth at $37^{\circ} \mathrm{C}$.

\begin{tabular}{|c|c|c|c|}
\hline Isolate code & $\begin{array}{c}\text { Ratio of } \\
\text { Zone size to } \\
\text { Colony size } \\
\text { (ZS/CS) }\end{array}$ & $\begin{array}{c}\text { C.F.U./ml } \\
\times 10^{6}\end{array}$ & $\begin{array}{c}\text { Chitinase } \\
\text { activity } \\
(\mathrm{U} / \mathrm{ml})\end{array}$ \\
\hline JF-1 & 3.5 & 197 & 225.375 \\
\hline JF-9 & 2.0 & 92 & 271.334 \\
\hline $\mathrm{JF}-10$ & 1.76 & 291 & 173.447 \\
\hline JF-14 & 2.66 & 1.52 & 295.112 \\
\hline JF-16 & 2.0 & 0.44 & 281.334 \\
\hline JF-20 & 2.8 & 134 & 200.516 \\
\hline JF-24 & 1.8 & 93 & 64.849 \\
\hline JF-25 & 2.05 & 0.91 & 73.495 \\
\hline JF-27 & 4.0 & 1.31 & 143.749 \\
\hline JF-28 & 5.0 & 96 & 179.416 \\
\hline JF-35 & 1.3 & 1.14 & 162.318 \\
\hline JF-38 & 2.25 & 1.73 & 181.061 \\
\hline$J F-41$ & 2.22 & 1.36 & 79.980 \\
\hline JF-42 & 1.75 & 1.92 & 62.687 \\
\hline $\mathrm{JF}-47$ & 4.5 & 1.11 & 162.123 \\
\hline JF-50 & 2.66 & 1.51 & 95.112 \\
\hline JF-55 & 3.5 & 1.18 & 125.375 \\
\hline JF-57 & 4.0 & 2.19 & 143.749 \\
\hline JF-59 & 1.5 & 159 & 174.041 \\
\hline JF-60 & 3.0 & 96 & 108.082 \\
\hline JF-62 & 5.0 & 58 & 199.416 \\
\hline JF-65 & 3.0 & 1.52 & 145.437 \\
\hline JF-66 & 3.3 & 76 & 216.991 \\
\hline JF-68 & 2.1 & 156 & 230.214 \\
\hline JF-70 & 2.9 & 1.23 & 301.548 \\
\hline JF-81 & 0.8 & 143 & 231.295 \\
\hline JF-82 & 1.2 & 245 & 112.174 \\
\hline JF-83 & 1.2 & 2.76 & 98.324 \\
\hline JF-84 & 0.8 & 3.4 & 45.78 \\
\hline JF-85 & 1.25 & 7.9 & 117.651 \\
\hline
\end{tabular}

From 85 isolates only 27 isolates (35.29\%) showed vivid zone of chitin hydrolysis. Korany et al (Korany et al., 2019) reported that among the thirty four isolates only four isolates produced zones of clearance (hydrolysis) on chitin agar medium. Similarly Ajayi et al. (2016) had isolated 36 chitinolytic isolates but selected 24 on the basis of highest chitnolytic index. Since chitinases are able to diffuse through agar, methods to identify chitinolytic bacteria are generally based on monitoring the hydrolysis of chitin polymer incorporated into agar medium (Hardoko et al., 2020).

Further twelve isolates were selected on the basis of chitinolytic activity units shown in Table 2. Among isolates JF70 yielded maximum chitinase activity $(301.55 \mathrm{U} / \mathrm{ml})$. This was followed by the isolate JF14 (295.11 U/ml) and the least producing chitinases was JF 59 (174..04 U/ml) shown in Table 2 following five days of submerged fermentation. All the twelve isolates were mesophilic and thermostable exposed their ability to work in harsh environmental conditions. Chitin being the second most abundant carbohydrate on the earth, provides richness in environment suitable for their survival and propagation of the chitinolytic microorganisms. Thus, the copious number of bacterial isolates being reported here and the previous studies is not surprising. Organisms containing chitin in their structure like fungi and insects produce chitinases for their growth and development purpose but bacteria produce chitinases in their saprophytic phase only to get carbon and nitrogen from chitin polymer (LacombeHarvey et al., 2018; Veliz et al., 2017). In the present study $71.42 \%$ of the samples represented soil's different nature. Soil bacteria are excellent sources of chitinolytic enzymes and could be use preferably for catabolic conversion of chitinous waste into useful products for diverse applications in biotechnology, medicine and agriculture (Schmitz et al., 2019; Sunny et al., 2018).

\section{Conclusion}

This is the first study to report comparison in the chitin extracted from blue edible crab and market purchased chitin. Characterization of chitin was carried out with FT-IR and XRD analysis. It is concluded that purified chitin of analytical grade is comparable to the Sigma and Roth brand, can be prepared from chitin wastes collected from edible blue crabs heaps in sea food markets by chemical methods which can not only provide purified chitin but also solve the environmental problems by converting the chitin to useful purpose for production of chitinolytic bacteria and various useful products can be exploited for diverse industrial purposes.

\section{References}

AJAYI, A., ONIBOKUN, E., GEORGE, F. and ATOLAGBE, O., 2016. Isolation and characterization of chitinolytic bacteria for chitinase production from the African Catfish, Clarias gariepinus (Burchell, 1822). Research Journal of Microbiology, vol. 11, no. 4, pp. 119-125. http://dx.doi.org/10.3923/jm.2016.119.125. 
ALI, M.H., ALJADAANI, S., KHAN, J., SINDI, I., ABORAS, M. and ALY, M.M., 2020. Isolation and molecular identification of two chitinase producing bacteria from marine shrimp shell wastes. Pakistan Journal of Biological Sciences, vol. 23, no. 2, pp. 139-149. http://dx.doi.org/10.3923/pjbs.2020.139.149. PMid:31944073.

ASIF, T., JAVED, U., ZAFAR, S.B., ANSARI, A., QADER, S.A.U. and AMAN, A., 2019. Bioconversion of colloidal chitin using novel chitinase from Glutamicibacter uratoxydans exhibiting antifungal potential by hydrolyzing chitin within fungal cell wall. Waste and Biomass Valorization, vol. 11, no. 8, pp. 4129-4143. http://dx.doi.org/10.1007/s12649-019-00746-2.

BEANEY, P., LIZARDI-MENDOZA, J. and HEALY, M., 2005. Comparison of chitins produced by chemical and bioprocessing methods. Journal of Chemical Technology \& Biotechnology, vol. 80, no. 2, pp. 145-150.

ELSOUD, M.M.A. and EL KADY, E., 2019. Current trends in fungal biosynthesis of chitin and chitosan. Bulletin of the National Research Centre, vol. 43, no. 1, pp. 59. http://dx.doi.org/10.1186/ s42269-019-0105-y.

GADGEY, K.K. and BAHEKAR, A., 2017. Studies on extraction methods of chitin from crab shell and investigation of its mechanical properties. International Journal of Mechanical Engineering and Technology, vol. 8, no. 2, pp. 220-231.

GUPTA, N., KUMAR, A., LAKSH, ANGURAL, S. and RANA, M., 2017. Process optimization of extracellular chitinase production from Bacillus sp. Isolated from fish waste Dumping site. European Journal Pharmaceutical and Medical Research, vol. 4, no. 9, pp. 474-480.

HARDOKO, JOSEPHINE, C., HANDAYANI, R. and HALIM, Y., 2020. Isolation, identification and chitinolytic index of bacteria from rotten tiger shrimp (Penaeus monodon) shell. AACL Bioflux, vol. 13, no. 1, pp. 360-371.

JABEEN, F. and QAZI, J., 2014. Isolation of chitinase yielding Bacillus cereus JF68 from soil employing an edible crab shell chitin. Journal of Scientific and Industrial Research, vol. 73, no. 12, pp. 771-776

JAHANGIRI, R., JAMIALAHMADI, K., BEHRAVAN, J. and NAJAFI, M. F., 2019. Purification and partial characterization of chitinase from a novel strain Aeromonas sp. PTCC 1691. Journal of Materials and Environmental Science, vol. 10, no. 7, pp. 590-597.

JUNG, W.-J. and PARK, R.-D., 2014. Bioproduction of chitooligosaccharides: present and perspectives. Marine Drugs, vol. 12, no. 11, pp. 5328-5356. http://dx.doi.org/10.3390/ md12115328. PMid:25353253.

KAYA, M., LELEŠIUS, E., NAGROCKAITE், R., SARGIN, I., ARSLAN, G., MOL, A., BARAN, T., CAN, E. and BITIM, B., 2015. Differentiations of chitin content and surface morphologies of chitins extracted from male and female grasshopper species. PLoS One, vol. 10, no. 1, pp. e0115531. http://dx.doi.org/10.1371/journal.pone.0115531. PMid:25635814.

KORANY, S.M., MANSOUR, A.N., EL-HENDAWY, H.H., KOBISI, A.N.A. and ALY, H.H., 2019. Entomopathogenic efficacy of the chitinolytic bacteria: Aeromonas hydrophila isolated from Siwa Oasis, Egypt. Egyptian Journal of Biological Pest Control, vol. 29, no. 1, pp. 16. http://dx.doi.org/10.1186/s41938-019-0116-x.

KUMAR, A. and ZHANG, K.Y.J., 2019. Human chitinases: structure, function, and inhibitor discovery. In: Q. YANG and T. FUKAMIZO, eds. Targeting chitin-containing organisms. Singapore: Springer, pp. 221-251.

LACOMBE-HARVEY, M., BRZEZINSKI, R. and BEAULIEU, C., 2018. Chitinolytic functions in actinobacteria: ecology, enzymes, and evolution. Applied Microbiology and Biotechnology, vol.
102, no. 17, pp. 7219-7230. http://dx.doi.org/10.1007/s00253018-9149-4. PMid:29931600.

LIU, K., DING, H., YU, Y. and CHEN, B., 2019. A cold-adapted chitinase-producing bacterium from Antarctica and Its potential in biocontrol of plant pathogenic fungi. Marine Drugs, vol. 17, no. 12, pp. 695. http://dx.doi.org/10.3390/md17120695. PMid:31835449.

LOC, N.H., HUY, N.D., QUANG, H.T., LAN, T.T. and THU HA, T.T., 2019. Characterisation and antifungal activity of extracellular chitinase from a biocontrol fungus, Trichoderma asperellum PQ34. Mycology, vol. 11, no. 1, pp. 38-48. http://dx.doi.org/10. 1080/21501203.2019.1703839. PMid:32128280.

NARUDIN, N.A.H., MAHADI, A. H., KUSRINI, E. and USMAN, A., 2020. Chitin, chitosan and submicron-sized chitosan particles prepared from Scylla serrata shells. Materials International, vol. 2, no. 2, pp. 139-149.

OYELEYE, A. and NORMI, Y.M., 2018. Chitinase: diversity, limitations, and trends in engineering for suitable applications. Bioscience Reports, vol. 38, no. 4, pp. BSR2018032300. http://dx.doi. org/10.1042/BSR20180323. PMid:30042170.

PANDHARIPANDE, S.L. and BHAGAT, P.H., 2016. Synthesis of chitin from crab shells and its utilization in preparation of nanostructured film. International Journal of Science, Engineering and Technology Research, vol. 5, no. 5, pp. 1378-1383

PIGHINELLI, L., BROQUÁ, J., ZANIN, B.G., FLACH, A., MALLMANN, C., TABORDA, F.G.D., MACHADO, L.E.L., ALVES, S.M.L., SILVA, M.M. and DIAS R.J.S.P., 2019. Methods of chitin production a short review. American Journal of Biomedical Science \& Research, vol. 3, no. 4, pp. 307-314.

RAMESHTHANGAM, P., SOLAIRAJ, D., ARUNACHALAM, G. and RAMASAMY, P., 2018. Chitin and Chitinases: biomedical and environmental applications of chitin and its derivatives. Journal of Enzymes, vol. 1, no. 1, pp. 20-43. http://dx.doi.org/10.14302/ issn.2690-4829.jen-18-2043.

RAY, L., PANDA, A.N., MISHRA, S.R., PATTANAIK, A.K., ADHYA, T.K., SUAR, M. and RAINA, V., 2019. Purification and characterization of an extracellular thermo-alkali stable, metal tolerant chitinase from Streptomyces chilikensis RC1830 isolated from a brackish water lake sediment. Biotechnology Reports, vol. 21, pp. e00311. http://dx.doi.org/10.1016/j.btre.2019.e00311. PMid:30775271.

SADFI, N., CHERIF, M., FLISS, I., BOUDABBOUS, A. and ANTOUN, H., 2001. Evaluation of bacterial isolates from salty soils and Bacillus thuringiensis strains for the biocontrol of Fusarium dry rot of potato tubers. Journal of Plant Pathology, vol. 82, no. 2, pp. 101-118.

SCHMITZ, C., AUZA, L.G., KOBERIDZE, D., RASCHE, S., FISCHER, R. and BORTESI, L., 2019. Conversion of chitin to defined chitosan oligomers: current status and future prospects. Marine Drugs, vol. 17, no. 8, pp. 452. http://dx.doi.org/10.3390/md17080452. PMid:31374920.

SEKI, H., 1965. Microbiological studies on the decomposition of chitin in marine environment-IX. Journal of the Oceanographical Society of Japan, vol. 21, no. 6, pp. 253-260. http://dx.doi. org/10.5928/kaiyou1942.21.253.

SONG, W., ZHANG, N., YANG, M., ZHOU, Y., HE, N. and ZHANG, G., 2020. Multiple strategies to improve the yield of chitinase a from Bacillus licheniformis in Pichia pastoris to obtain plant growth enhancer and GlcNAc. Microbial Cell Factories, vol. 19, no. 1, pp. 181. http://dx.doi.org/10.1186/s12934-020-01440-y. PMid:32933546.

SUN, X., LI, Y., TIAN, Z., QIAN, Y., ZHANG, H. and WANG, L., 2019. A novel thermostable chitinolytic machinery of Streptomyces sp. F-3 consisting of chitinases with different action modes. 
Biotechnology for Biofuels, vol. 12, no. 1, pp. 136. http://dx.doi. org/10.1186/s13068-019-1472-1. PMid:31171937.

SUNNY, N.E., KUMAR, S.R. and KUMAR, S.V., 2018. A review on chitinase synthesis from varied sources and its applications towards environment. Research Journal of Pharmacy and Technology, vol. 11, no. 9, pp. 4200-4208. http://dx.doi. org/10.5958/0974-360X.2018.00770.9.

THIRUNAVUKKARASU, N. and SHANMUGAM, A., 2009. Extraction of chitin and chitosan from mud crab Scylla tranquebarica (Fabricius, 1798). International Journal on Applied Bioengineering, vol. 4, no. 2, pp. 31-33. http://dx.doi.org/10.18000/ijabeg.10048.

VELIZ, E. A., MARTÍNEZ-HIDALGO, P. and HIRSCH, A. M., 2017. Chitinase-producing bacteria and their role in biocontrol. AIMS microbiology, vol. 3, no. 3, pp. 689.
WANG, Y., PEDERSEN, C.M., DENG, T., QIAO, Y. and HOU, X., 2013. Direct conversion of chitin biomass to 5-hydroxymethylfurfural in concentrated $\mathrm{ZnCl} 2$ aqueous solution. Bioresource Technology, vol. 143, pp. 384-390. http://dx.doi.org/10.1016/j. biortech.2013.06.024. PMid:23819974.

XU, T., QI, M., LIU, H., CAO, D., XU, C., WANG, L. and QI, B., 2020. Chitin degradation potential and whole-genome sequence of Streptomyces diastaticus strain CS1801. AMB Express, vol. 10, no. 1, pp. 29. http://dx.doi.org/10.1186/s13568-020-0963-6. PMid:32036475.

YADAV, M., GOSWAMI, P., PARITOSH, K., KUMAR, M., PAREEK, N. and VIVEKANAND, V., 2019. Seafood waste: a source for preparation of commercially employable chitin/chitosan materials. Bioresources and Bioprocessing, vol. 6, no. 1, pp. 8. http://dx.doi.org/10.1186/s40643-019-0243-y. 